\title{
POTENTIAL DEVELOPMENT OF RURAL TOURISM IN PENATIH VILLAGE
}

\author{
I Wayan Pantiyasa, Ni Luh Supartini. Sekolah Tinggi Pariwisata Bali \\ International \\ pantiyasawayan@yahoo.com,ms_tini88@yahoo.com
}

\begin{abstract}
The development of tourism in Bali has a real effect on economy in Bali. Development and promotion of tourism that has been done should be capable to be sustained and maintained in the future. Tourism sustainability discourse must involve the commitment from all parties to maintain the sustainability of the natural, social, economic and cultural community as the basic capital of tourism. Tourism Department of Denpasar city is trying to develop the alternative tourism for reducing the negative effects of mass tourism and empowering rural communities through the development of rural tourism. One of the villages targeted is Penatih village which is a village that has the potential resources to be developed into a rural tourism with traditional culture (art), social order, Subak and other. The approach used in this research was qualitative descriptive. The data were collected through interview, observation, documentation and conduct Focus Group Discussion (FGD). Then the data were analyzed by using SWOT analysis. From the result of study, there were found some potential that can be developed and packaged in rural tourism. And also this research provides the strategies to develop this village to be a rural tourism
\end{abstract}

Keywords: rural tourism development, management, tourism sustainability.

\section{Introduction}

Dynamically, the issue of tourism development has been developed in a variety of terminology such as sustainable tourism development, rural tourism, ecotourism, which is trying to ensure that the travel can be implemented in real tourist destination especially in village. One approach of alternative tourism development is rural tourism for sustainable rural development. The main point of rural tourism can be seen in the lifestyle and quality of life in society. Authenticity is also influenced by economic conditions, physical and social rural area, such as space, cultural heritage, agriculture, landscape, services, tourism and cultural history, as well as unique experience and exotic regional specialties. Thus, the model of rural tourism should be continued and developed to be an identity or characteristic of certain area creatively.

Therefore, the model of rural tourism for sustainable rural development must continue creatively to develop a new identity or characteristic of the village 
to meet the goal of problem solving associated with the economic crisis of the rural areas. The increase due to complicated various forces, which cause the number of employments, reduced and the wealth of rural communities increased. One way out to resolve the crisis is through the development of small scale rural tourism industries, so it is able to compete and being excellent in the development of rural areas, and create new jobs and increased prosperity.

Related to these efforts, the government of Denpasar city through the Department of Tourism has made program to develop tourism sector such as tourism area of Sanur that is very famous in the world by creating "city tour development', the implementation of Denpasar festival and other efforts. Denpasar city government is trying to find an alternative tourism development for reducing the negative effects of mass tourism and empower rural communities through the development of rural tourism. One of the villages targeted is Penatih village. Penatih village is one village in East Denpasar district, the village that has the potential to be developed into a rural tourism with traditional culture (art), social community, Subak and others. With the potential resources, Penatih village need to have a concept of tourism product development in accordance with the characteristics of the local area.

\section{Literature Review}

Rural tourism is "a form of integration between attractions, accommodation and supporting facilities that are presented in a structure of a society that blends with the procedures invitation prevailing tradition" (Nuryanti, 1993). Another opinion says "rural tourism is a rural area that offers the whole atmosphere that reflects the authenticity of the countryside both in social and economic life, social culture, customs typical, architecture and structure of the village spatial economic activities that are unique and interesting. It also has the potential to be developed such as tourism component attractions, accommodations, eating and drinking and other travel needs "(Tourism Nucleus, 1999).

According to pattern, process and type of management, rural tourism is divided into two forms namely, enclave type and open type (Wikipedia, 2011):

1) Enclave type

Enclave type was characterized by the following characters:

a. Limitation of land that is equipped with specific infrastructure. This type is appropriated to be offered for international market.

b. The general location separate from the local population so that its impact is expected to be controlled.

2) Open type

This type is characterized by the life style and the structure of land which merged with local community. The profit which is gained from rural tourism development can be distributed to all local community; however the negative effect appeared are difficult to be handled because it is merged with local community.

The principle of the development of rural tourism is one of the alternative tourism products that can provide support for sustainable rural development has principles include:

a. utilize the facilities and infrastructure of local communities 
b. provide benefit the local community

c. involve local communities

d. small scale to facilitate the establishment of a reciprocal relationship with the local community

e. implement the rural tourism product development, and some of the underlying criteria such as, among others:

- Providing facilities and infrastructure owned by local communities who normally encourage community participation and ensure their access to physical resources is a stepping stone for the development of rural tourism.

- Encouraging increased income from agriculture and other traditional economic activities.

- The locals have an effective role in the process of decision-making on forms of tourism that utilizes environmental areas and locals earn decent revenue sharing from tourism activities.

- Encouraging the development of local entrepreneurship.

While in the planning principles that need to be included in the "preliminary, planning" that (1) although there are many areas around the current village, we can involve all areas to be tourist destination and (2) the potential of rural tourism also depends on the willingness of local people to be creative, innovative, and cooperative. Not all tourism activities undertaken in the village are village activities, therefore, the village must have some important points to be viisted by the tourist such as:

a. The uniqueness, authenticity, the distinctive nature.

b. The strategic location to other famous places.

c. In connection with a group or a civilized society.

d. Provide opportunity to grow both in terms of basic infrastructure, as well as other facilities.

Based on the characteristics above, there are some target should be achieved in developing rural tourism are:

1) Establishment of rural tourism development model based on sustainable tourism / friendly environmentally.

2) Integrate development by identifying and analyzing existing potentials, determine patterns of structuring landscape tread area, as well as making the possibility of alternative development.

3) Realization of rural tourism arrangement based on the use of zoning for preserving the environment and maintaining the safety of visitors.

4) Realization of rural tourism which is based on the pattern of the village and the architecture of traditional houses.

5) The realization of the ability of local communities to preserve, explore, develop the diversity of art and culture, society, which is useful for completeness of the tourist attractions that can be enjoyed by visitors and the availability of food typical of the area of raw materials in the village.

6) The consultant when needed by the community 
7) The community empowerment as one of the central themes in community development should be placed and oriented in the same direction and a step with a new paradigm of development approaches.

8) According to Nasikun (2000: 27) states: "The new development also must be the principle that development must first and foremost be done on initiative and boost the interests of the public, the public should be given the opportunity to be involved in the whole process of planning and implementation construction; including ownership and control of the infrastructure so that the distribution of profits and benefits would be more fair to the public.

9) An important aspect of a community empowerment program is a program organized by the community, able to answer the basic needs of society, to support the involvement of the poor and other marginalized groups, built from the resources of the People to the cultural values of society, environmental impacts, not creating dependence, related parties involved (government agencies, research institutions, universities, NGOs, private sector and other parties), and implemented a sustainable manner.

Some researchers have been conducted in area of rural tourism. Suzanne Wilson (1997) in an wrote about Factors for Success in Rural Tourism Development in International Journal. The aims of the study was to identify and examine the factors - factors that influenced rural communities successfully in developing tourism and entrepreneurial opportunities. The result showed the importance of community approach to the development of tourism. The tourism development and entrepreneurship could not be run without the participation of business people directly and indirectly in tourism.

Another one is William P. Stewart (1996) conducted a research about Rural Tourism Development : Shifting Basis of Community Solidarity. This study suggests that community solidarity is considered one of the major advocates for the development of rural tourism. This study discusses the impact of the development of rural tourism on local communities.

\section{Methodology}

This research was conducted in Penatih village, East Denpasar district. This village was based on the fact that Penatih village is one village that wins the rural tourism in village tourism competition in Bali. This study used qualitative method in doing the research.

Based on the sources, the data in this study can be classified into two, namely:

1) The primary data source was data obtained from the first source or directly obtained both orally and in writing from respondents and informants. The data includes the data observation, informant interviews (government agencies, community leaders, tourism businesses and academia), and data from filling the questionnaire.

2) Secondary data sources were data obtained from supporting sources such as data in the form of documentation related to the village and district maps, village profiles obtained from governmental institutions, previous researches, the study of literature or other references. 
The data were collected through some methods such as:

1) Interview, namely interviewing stakeholders who know the potential tourism appeal and experts / expert or resource using the instrument guide the interview (interview guide) that had been prepared previously. From interviews will be obtained data needed as base material external and internal analysis of technical organizations implementing a tourist attraction to formulate development strategies Penatih village.

2) Observation, namely observation or direct observation in the field to find out the tourist attraction in a bid for the development of tourism in the village Penatih.

3) Document / literature, which is a technique to obtain data to study the documents relating to the problems studied. The technique is applied in form recording or pictures.

4) Documentation of obtaining data through the documents related to the study.

5) Focus Group Discussion (FGD) was held to discuss the potential and the target achieved in developing Penatih as aone of rural tourism in Denpasar. FGD was attended by the Head of Tourism Denpasar city and its board, Pok Darwis Penatih and some tourism expert associated with development of rural tourism.

This study used SWOT analysis to analyze the data. SWOT analysis includes efforts to identify the strengths, weaknesses, opportunities, and threats that determine performance. External Information about opportunities and threats can be obtained from many sources, including tourists, government documents, and other sources. These elements include strength SWOT (strength) and weakness (weakness) as internal factors, as well as the chance (opportunity) and threats (threats ) as external factors.

\section{Result and Discussion}

Based on the data, the researcher found that there were some potential of tourism in Penatih village such as:

1) Tourist Attraction

a. Natural and human made

These natural attractions were in the form of rice fields and jogging track. Jogging track has been built along $2 \mathrm{~km}$ in the midst of rice fields. Jogging track can only be passed by two-wheeled vehicles and bicycles. Jogging track around there are still quite extensive rice fields and can be used as agricultural attractions.

b. Socio-Cultural

There was an interesting from Penatih village in term of socio-cultural, that is making a gong. A gong is known as the manufacture of traditional musical instruments. The traditional music instruments were various for the ceremony and other traditional purposes. The existence "pande gong" was done for generations. Gamelan is a traditional musical instrument known since the time of Majapahit Kingdom. This instrument is normally used to accompaning religious ceremonies, welcoming guests, and in the traditional parties.

"Pande gamelan" in producing handicrafts such as Trompong Gong Kebyar certainly need materials and tools as the most important element in the manufacturing process. 
c. Centre of traditional Balinese cake

a. Such as sumping waluh that made from materials such as rice flour, pumpkin , half of young coconut, sugar, salt and other supporting materials are then wrapped in banana leaves and steamed. It was sweet and savory.

b. Bantal cake which is same as nagasari cake that contains the contents of tangerines bananas or plantains. The difference lies in the ingredients used are sticky while nagasari made from wheat flour

c. Laklak cake is made from rice flour, coconut milk, suji leaves, baking powder, salt, grated coconut, and eaten with brown sugar glaze sauce.

d. Home made of arts

This train also produced in traditional Balinese clothes for men and women, which is produced by the young people in the banjo. In addition, the do not only sell but also rent some clothes and their attributes for events such as performing mengambel baleganjur and some jewelry were rented for dancer.

e. Accommodation

This village also provide several accommodation facilities such as villas, lodging houses are simple and can dimodfikasi and deserves to stay tourists.

f. Food Centre

Village of Penatih provide places to eat and drink for the tourists especially traditional cuisine such as Bali Guling Men Siring.

g. Transportation and communication means

Tourism infrastructure such as roads, transportation and communication infrastructure are well available. The availability of the accessibility of tourism is essential to support tourism activities. Penatih villages have complete accessibility of tourism which includes road access, and access to airports.

h. Accessibility

The location of Penatih village is strategic near the city centre and other tourism objects such as Sanur, Ubud Gianyar, tourist attraction Sangeh, Taman Ayun, also close to the Ngurah Rai Airport . 
In summary the results of this identification are presented in the following table .

\begin{tabular}{|c|c|}
\hline STRENGHTHESS & WEAKNESSES \\
\hline $\begin{array}{l}\text { l.Diversity tourism potential } \\
\text {.Availability of accommodation } \\
\therefore \text { Availability of places to eat and drink } \\
\text { l.Facilities, roads, transportation are } \\
\text { good } \\
\text {.Provide supporting facilities such as } \\
\text { laundry rating available } \\
\text {. Environmental support } \\
\text { 5. Community relative to receive tourist }\end{array}$ & $\begin{array}{l}\text { The management is not optimal } \\
\text { Many dogs } \\
\text { Promotion is not maximized } \\
\text { People do not consciously develop } \\
\text { tourism } \\
\text { Low quality of human resources }\end{array}$ \\
\hline OPPORTUNITIES & THREATS \\
\hline $\begin{array}{l}\text { 1. Regulation of government in } \\
\text { developing rural tourism } \\
\text {. Tourists tend to enjoy rural tourism } \\
\therefore \text { The improvement of alternative } \\
\text { tourism market for tourists who like } \\
\text { rural tourism }\end{array}$ & $\begin{array}{l}\text { The conversion of rice field into } \\
\text { house. } \\
\text { Increasing the growth of rural tourism } \\
\text { in all regencies in Bali. } \\
\text { The safety is not stabile yet. } \\
\text { Difference culture of guest and local } \\
\text { community that leads } \\
\text { misunderstanding }\end{array}$ \\
\hline
\end{tabular}

Inventory SWOT above then do a cross tabulation to determine the development strategy as follows .

1) SO strategy

a) Creating a group of local people to aware about rural tourism

b) Socializing the group to community

c) Planning for tourism attraction/product development

d) Planning for tourism product which is created based on the potential in Penatih village such as nature, culture and spiritual.

2) Strategi ST

a) Conduct an approach to government to minimize land conversion, lash, and other vulnerabilities.

b) Develop creativity to empower community - owned land so that a higher value

c) Develop networks to socialize various potential sanctuaries and various rules that must be applied

3) Strategi WO

a) The group approached by the District Government and banks to look for financial aid

b) Make rules about dog maintenance ( elimination of stray dogs)

c) If tourists visited the village, they must be explained what to do and don't in the village.

4) Strategi WT

a) Giving briefing to the local community about cross - cultural to the public 
b) Designing an effective promotional program with a special market segment for urban tourist village

c) In collaboration with various universities and other parties to undertake activities that can improve the quality of local human resources

From the explanation above, can be designed the strategy in forms of some programs including:

1) Establishment of operational organization to run the business of rural tourism

2) To disseminate to the public about the development of rural tourism will be conducted

3) Preparation of rules (role ) in the form of statutes and by laws

4) Making a plan of

a. Tourism product based on village potential

b. Marketing (Product, Price, Place of distribution and Promotion)

c. Operational

5) Find out travel agents to be in cooperation

6) Conduct study visit to other rural tourism destination

\section{Conclusion and Recomendations}

Based on the result of the study, the researchers suggest some recommendation to develop Penatih village to be rural tourism destination such as

1) Conduct a meeting between the group of people that have arranged (Pok Darwis) with community leaders in the village. This meeting aims to create operational group of rural tourism in running the rural tourism business.

2) The government of tourism enables to facilitate the requirement of this village.

3) Prepare the socialization to community that will be created rural tourism with the benefits and consequences.

4) For the Academic institution especially Sekolah TInggi Pariwisata Bali Internasional to give the training that are required by the community such as guiding training, English course, cooking and serving food and beverage skills. 


\section{REFERENCES}

Adams, W.M.,1990, Green Development and Sustainability in the Word,London: Routledge

Arikunto,Suharsimi, 2002, Prosedur Pe-nelitian suatu pendekatan Praktek, Rineka Cipta.Jakarta

Aronsson, Lars, 2000, The Development of Sustainable Tourism: London,Continum

Baiquni, M, 2002 "Integrasi Ekonomi dan Ekologi dari Mimpi Menjadi Aksi," dalam Wacana, III, 12,

Becker, Egon, \& T. Jahn (eds.),1999. Sustainability and The Social Sciences (New York: UNESCO and SOI

Depbudpar, 2009, pengembangan pari-wisata, jakarta

Derektorat Pemberdayaan Masyarakat depbudpar,2009pengembangan inti rakyat, Jakarta

Fakih, Mansour, 2001, Sesat Pikir Teori Pembangunan dan Globalisasi,Yogyakarta: Pustaka Pelajar dan Insist Press

Indriati, Etty,2001, Menulis Karya Ilmiah (artikel,Skripsi,Tesis dan desertasi, Gramedia Pustaka Utama, jakarta

Garrod, Brian,2001Local Partisipation in the Planning and Management of Eco Tourism: A Rivised Model Ap-proach, Bristol: University of The West Of England

Hajar Ibnu S, 1999, Dasar-dasar Metode-logi Penelitian Kwantitatif dalam Pendidikan, Raja Grafindo Prasa-da, Jakarta

Mowfort,Martin\& I, Munt,1998, Tourism and Sustainability New Tourism in the Word, London: Routedge

Richard Sharpley, 2000, "Tourism and Sustainable Development : Explor-ing the Theorical Divice” Journal of Sustainable Tourism, VIII (1-19)

Simamora.Bilson,2004, Panduan Riset Prilaku Konsumen, Gratmedia Pustaka Utama, Jakarta

Suansri, Potjana, 2003, Community Based Tourism Hand Book, Thailand: Rest Project

Sugiyono, 2000Metode Penelitian Bisnis, CV.alfa beta, Bandung

Journal of Business on Hospitality and Tourism 
Suryabrata, Sumadi, 1983, Metode Pene-litian, Raja Grafindo Prasada Jakarta

Timothy, DJ, 1999, "Participatory Plann-ing a View of Tourism in Indonesia" dalam Annuals Review of Tourism Research,XXVI (2), Jakarta 